\title{
On Thaicypris panhai gen. et sp. nov., a new herpetocypridine ostracod (Crustacea: Ostracoda: Cyprididae) from Thailand
}

\author{
Sukonthip SAVATENALINTON ${ }^{\circledR}$ \\ Department of Biology, Faculty of Science, Mahasarakham University, \\ Maha Sarakham 44150, Thailand. \\ Email: sukonthip.s@msu.ac.th \\ urn:1sid:zoobank.org:author:254994A1-C8E1-4242-ADF8-184661366B2D
}

\begin{abstract}
A new genus, Thaicypris gen. nov., in the tribe Herpetocypridini Kaufmann, 1900 of the subfamily Herpetocypridinae Kaufmann, 1900 is established to accommodate a new species from Thailand. The present contribution deals with the description of a new genus and species, Thaicypris panhai gen. et sp. nov., which is mainly characterized by the distinctive and raised, inwardly displaced selvage at the postero-ventral part of the right valve (RV) that is not parallel to the valve margin, the absence of an anterior inner list on the RV, the prominent and elevated double inner list on the posterior part of the left valve, the small and three-segmented Rome organ on the first antenna (A1), the spatulated terminal segment of the maxillular (Mx1) palp, the slender caudal ramus (CR) with long and thin Sp seta, the presence of basal triangle on the CR attachment, and the pointed projection at the terminal segment base of the prehensile palps. The hemipenis of the new genus and species is outstanding, especially the medial lateral shield which has a long, beak-shaped protrusion on the distal part. The discovery of this Thai taxon is the first record of the tribe Herpetocypridini in Thailand and the second species of the tribe in Southeast Asia.
\end{abstract}

Keywords. Herpetocypridini, crustacean, taxonomy, biodiversity, Southeast Asia.

Savatenalinton S. 2022. On Thaicypris panhai gen. et sp. nov., a new herpetocypridine ostracod (Crustacea: Ostracoda: Cyprididae) from Thailand. European Journal of Taxonomy 787: 86-103.

https://doi.org/10.5852/ejt.2021.787.1617

\section{Introduction}

Herpetocypridinae Kaufmann, 1900 is a large subfamily of Cyprididae Baird, 1845 which includes 15 genera and 155 species (Meisch et al. 2019). The taxonomic studies on the subfamily were carried out in several taxonomic publications. The revision of the European Herpetocypris Brady \& Norman, 1889 was extensively made by Gonzalez Mozo et al. (1996) while the taxonomy of the entire subfamily was revised by Martens (2001). These works revealed the morphology of both soft parts and valves, which has provided significant taxonomic characters within the subfamily. Recently, many species about which we previously had insufficient taxonomic information, have been redescribed, for example the species of Ilyodromus Sars, 1894 (Shearn et al. 2014) and Stenocypria G.W. Müller, 1901 (Scharf et al. 2020). Moreover, the investigations into the detailed structures of both valves and soft parts offered more 
distinguishing features. For example, the features of the marginal pore canals of the valves (Martens 2001), the segmentation of the Rome organ on the A1 and the internal pegs on the LV (Shearn et al. 2014).

Subfamily Herpetocypridinae is divided in four tribes: Herpetocypridini Kaufmann, 1900, Isocypridini Rome, 1965, Psychrodromini Martens, 2001 and Stenocypridini Ferguson, 1964 (Meisch et al. 2019). The most diverse tribe is Stenocypridini, comprising five genera and 84 species, followed by Herpetocypridini with three genera and 42 species. Herpetocypridini, the nominal tribe, was defined chiefly by the elongated and laterally flattened carapace, the inwardly displaced selvage on the LV or the $\mathrm{RV}$, the absence of marginal septa, the A1 Rome organ which is medium to large and segmented with up to three parts, the spatulated terminal segment of the Mx1-palp, and the symmetrical CR which has the Sp seta (see Martens 2001). At present, three genera are assigned to this tribe: Candonocypris Sars, 1896, Herpetocypris Brady \& Norman, 1889 and Ilyodromus Sars, 1894.

Thus far, only one representative of the tribe Herpetocypridini has been reported from Southeast Asia, Ilyodromus lanoaensis Victor \& Fernando, 1981, which was described from Philippines (Victor \& Fernando 1981). In Thailand, members of the subfamily Herpetocypridinae have so far been restricted to two genera of Stenocypridini: Chrissia Hartmann, 1957 and Stenocypris Sars, 1889 (see Savatenalinton \& Suttajit 2016; Moonchaisook \& Savatenalinton 2020).

\section{Material and methods}

A sample was collected with a hand net (mesh size $200 \mu \mathrm{m}$ ), preserved in $70 \%$ ethanol and then specimens were sorted using a binocular microscope in the laboratory. Soft parts and valves were separated under a stereo microscope (Olympus SZ40) and subsequently soft parts were dissected in glycerine, sealed on glass slides and valves were stored dry on micropalaeontological slides. A camera lucida, attached to the compound microscope, was used for drawing of soft parts. Valves were examined and illustrated using a scanning electron microscope (JEOL JSM6460LV - at the Faculty of Science, Mahasarakham University, Thailand). The model of limb chaetotaxy proposed by Broodbakker \& Danielopol (1982) is followed, together with the revised version for the second antenna and for the thoracopods, respectively, proposed by Martens (1987) and Meisch (2000). The distal claws of the male second antenna (G1, G3, GM and Gm) follow the model revised by Scharf et al. (2020). The type materials of this species are deposited in the ostracod collection in the museum of the Faculty of Science, Mahasarakham University, Maha Sarakham, Thailand.

\section{Abbreviations used in text and figures}

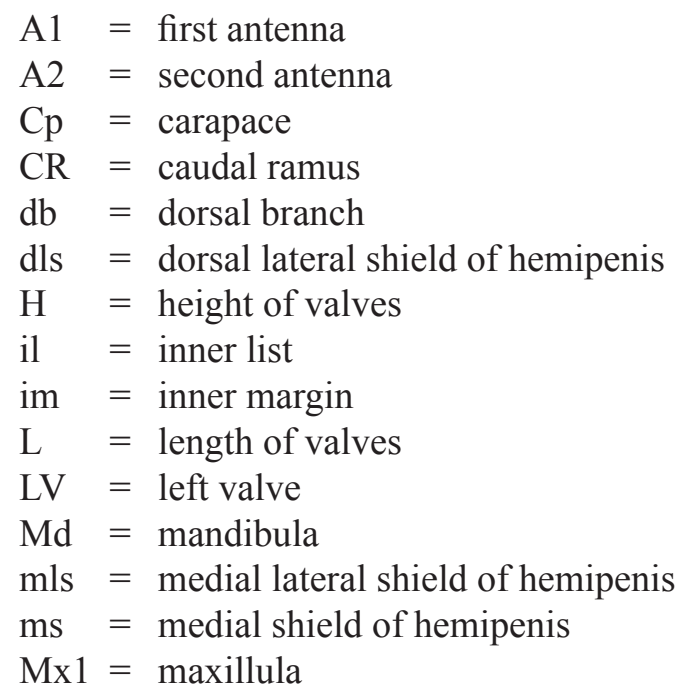




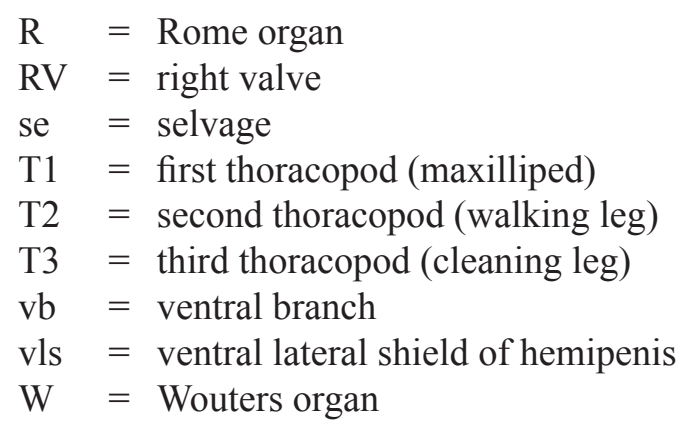

\section{Repositories}

MSU = Mahasarakham University, Maha Sarakham, Thailand

MSU-ZOC = ostracod collection of the museum of the Faculty of Science, Mahasarakham University, Maha Sarakham, Thailand

\section{Results}

Class Ostracoda Latreille, 1802

Subclass Podocopa G.O. Sars, 1866

Order Podocopida G.O. Sars, 1866

Suborder Cypridocopina Jones, 1901

Superfamily Cypridoidea Baird, 1845

Family Cyprididae Baird, 1845

Subfamily Herpetocypridinae Kaufmann, 1900

Tribe Herpetocypridini Kaufmann, 1900

\section{Genera included}

Candonocypris Sars, 1896, Herpetocypris Brady \& Norman, 1889, Ilyodromus Sars, 1894 and Thaicypris gen. nov.

Thaicypris gen. nov.

urn:1sid:zoobank.org:act:C3208FD2-9CC0-42B3-8342-240AA0A79E44

\section{Type species}

Thaicypris panhai gen. et sp. nov. (here designated)

\section{Etymology}

The name is a combination of 'Thai-' and the existing generic name 'cypris' to refer to the discovery of this taxon from Thailand.

\section{Diagnosis}

Cp elongated (length ca $2.2 \mathrm{~mm}$ ), in dorsal view elongated with widened posterior half (not compressed), LV overlapping RV on all sides, LV with prominent double posterior inner list, RV with prominent and raised, inwardly displaced selvage at postero-ventral part appearing not parallel to valve margin and without anterior and posterior inner list, fused zone of LV wider than RV, marginal pore canals present. Calcified inner lamella of both valves wide anteriorly, narrower posteriorly. A1 with small Rome organ. Natatory setae on A2 long (reaching tip of terminal claws). Md-palp with three claws and four setae on terminal segment, $\alpha$-seta elongated with narrow base and long, needle-like tip, $\gamma$-seta large, elongated. Mx1-palp with spatulated terminal segment and basal segment with seven setae. Setae d1 and 
d2 on T2 subequal in length. CR symmetrical and slender, Sp seta long and slender (true seta), claw Ga long, claw Gp short. CR attachment with basal triangle. Male T1 palps asymmetrical and with pointed projection at inner base of terminal segment. $\mathrm{ms}$ of hemipenis with widely rounded distal margin and without elongated protrusion, mls with long, beak-like distal part, vls with rounded margin and without protrusion.

\section{Differential diagnosis}

Thaicypris gen. nov. is similar to Herpetocypris and Ilyodromus. In the new genus, the inwardly displaced selvage on the RV postero-ventral part and the double posterior inner list on the LV are prominent, raised and lay far apart from the valve margins that are clearly different from conditions in the two related taxa. In addition, Thaicypris gen. nov. can be distinguished from them by the obviously slender CR with thin claws and setae, the small and three-segmented Rome organ and the different morphology of $\alpha-, \beta$ - and $\gamma$-setae on the Md-palp. The hemipenis structures of the new genus also represent significant differences, especially the long, beak-like protrusion on the distal part of the medial lateral shield that is not present in Herpetocypris and Ilyodromus or even in other herpetocypridine genera.

\section{Distribution}

Thailand (present study).

Thaicypris panhai gen. et sp. nov. urn:1sid:zoobank.org:act:A9E0AEBE-99FD-4CDD-9744-F950EDA7BD79

Figs $1-7$

\section{Diagnosis}

$\mathrm{Cp}$ in lateral view elongated (length ca $2.2 \mathrm{~mm}$ in female, ca $2 \mathrm{~mm}$ in male), greatest height situated at $2 / 3$ of length, $\mathrm{Cp}$ in dorsal view elongated with widened posterior half, greatest width situated at $2 / 3$ of length, valve surface smooth, LV overlapping RV on all sides. LV with a prominent double posterior inner list and a weak antero-ventral inner list. RV with prominent and raised, inwardly displaced selvage at postero-ventral part appearing not parallel to valve margin and without anterior and posterior inner list. Fused zone of LV wider than RV, especially at postero-ventral part of LV, marginal pore canals present. Calcified inner lamella of both valves wide anteriorly, narrower posteriorly. A1 with small Rome organ and small Wouters organ. Natatory setae on A2 long (reaching tip of terminal claws), male A2 with clawlike z1 and z2 setae, considerably reduced claw G1, claw G3 and GM reduced to thin setae, claw Gm large with strong teeth, length of GM ca half of length of Gm. Md-palp with three claws and four setae on terminal segment, $\alpha$-seta elongated, with narrow base and long, needle-like tip, $\beta$-seta stout and set with a few long and strong setules, $\gamma$-seta large, elongated, distally covered with long setules ca $2 / 3$ of its length. Mx1-palp with spatulated terminal segment, basal segment with seven setae, two large bristles on $3^{\text {rd }}$ endite smooth. Setae d1 and d2 on T2 of medium length and subequal. CR symmetrical, ramus and claws slender, Sp seta long and slender (true seta), reaching beyond tip of ramus, claw Ga long, claw Gp short (less than half length of claw Ga). CR attachment with basal triangle and two-branched distal part. Male T1 palps asymmetrical, right palp with subtriangular terminal segment, left palp with hook-like terminal segment, terminal segment of both palps with small pointed projection at inner base. Medial lateral shield of hemipenis proximally knob-like rounded and markedly long, beak-like distally.

\section{Differential diagnosis}

As Thaicypris gen. nov. is monospecific at present, the differential diagnosis is largely the same as for the genus. 


\section{Etymology}

The species is named in honor of Prof. Dr Somsak Panha (Chulalongkorn University, Thailand) for his outstanding work on animal biodiversity in Thailand and Southeast Asia as well as for his effort to encourage young scientists in taxonomy and systematics studies in Thailand for a long time.

\section{Type material}

\section{Holotype}

THAILAND - Maha Sarakham Province • $q$ (soft parts dissected in glycerine on a sealed glass slide and valves stored dry on a micropalaeontological slide); Nong Bua (swamp), Kantharawihai District; $16.319372^{\circ} \mathrm{N}, 103.29637^{\circ} \mathrm{E}$; 19 Jun. 2021; MSU-ZOC.314.

\section{Allotype}

THAILAND - Maha Sarakham Province • $\lesssim$ (stored as the holotype); same collection data as for holotype; MSU-ZOC.315.

\section{Paratype}

THAILAND - Maha Sarakham Province $\bullet 1$ (stored as the holotype); same collection data as for holotype; MSU-ZOC.316.

\section{Type locality}

A total of 2 female and 1 male specimens was collected at the type locality on 19 Jun. 2021. Accompanying ostracod fauna: Bradleystrandesia weberi (Moniez, 1892), Candona sp., Cypretta aculeata Savatenalinton, 2018, Cyprettadopsis sutura Savatenalinton, 2020, Dentocypria mesquitai Savatenalinton, 2017, Metacypris sp., Pseudocypretta maculata Klie, 1932, Pseudostrandesia mamarilorum (Victor \& Fernando, 1981), Pseudostrandesia striatoreticulata (Klie, 1932), Strandesia kraepelini (Müller, 1906), Vestalenula sp.

\section{Description}

\section{Female}

Measurements (in mm). LV: $\mathrm{L}=2238, \mathrm{H}=1119 ; \mathrm{RV}: \mathrm{L}=2214, \mathrm{H}=1071$.

CP IN LATERAL VIEW. Elongated (length ca $2.2 \mathrm{~mm}$ ), greatest height situated at $2 / 3$ of length, Cp in dorsal view elongated with widened posterior half, greatest width situated at $2 / 3$ of length, LV overlapping RV on all free margins, valve surface smooth with irregular dark green patches.

LV IN INTERNAL VIEW (Figs 1A-B, 2A-B, 3A). With both valve margins rounded, wider rounded posteriorly, dorsal margin arched, ventral margin somewhat straight, submarginal selvage anteriorly, anterior calcified inner lamella wide with weak and incomplete inner list (only on antero-ventral part), posterior calcified inner lamella narrow with a prominent double posterior inner list, fused zone wide and markedly wider at postero-ventral part, marginal pore canals present.

RV IN INTERNAL VIEW (Figs 1C-D, 2C-D, 3B). With both valve margins rounded, wider rounded posteriorly, dorsal margin arched, slightly more arched than that of LV, ventral margin somewhat straight, marginal selvage anteriorly, inwardly displaced selvage prominent and raised, on postero-ventral part appearing not parallel to valve margin, calcified inner lamella wide anteriorly, narrow posteriorly, without anterior and posterior inner list, width of fused zone somewhat regular along valve margin, narrower than that of $\mathrm{LV}$, marginal pore canals present.

A1 (Fig. 4A-C). Seven-segmented, first segment with one short dorso-subapical seta (not reaching tip of segment), two long ventro-apical setae and small Wouters organ. Second segment ca 1.5 times as 
wide as long, with one short dorso-apical seta (not reaching mid-length of next segment) and Rome organ small, three-segmented. Third segment bearing two setae: one long dorso-apical (reaching far beyond tip of terminal segment) and one short ventro-apical setae (reaching tip of next segment). Fourth segment with two long dorsal setae and two shorter ventral setae (shortest one reaching mid-length of penultimate segment). Fifth segment dorsally with two long setae, ventrally with two (one long, one shorter) setae, shorter one reaching far beyond tip of terminal segment. Penultimate segment with four long apical setae and one short seta (reaching mid-length of terminal segment). Terminal segment with three (two long, one short) apical setae and long aesthetasc ya, length of aesthetasc ya slightly shorter than that of short seta.

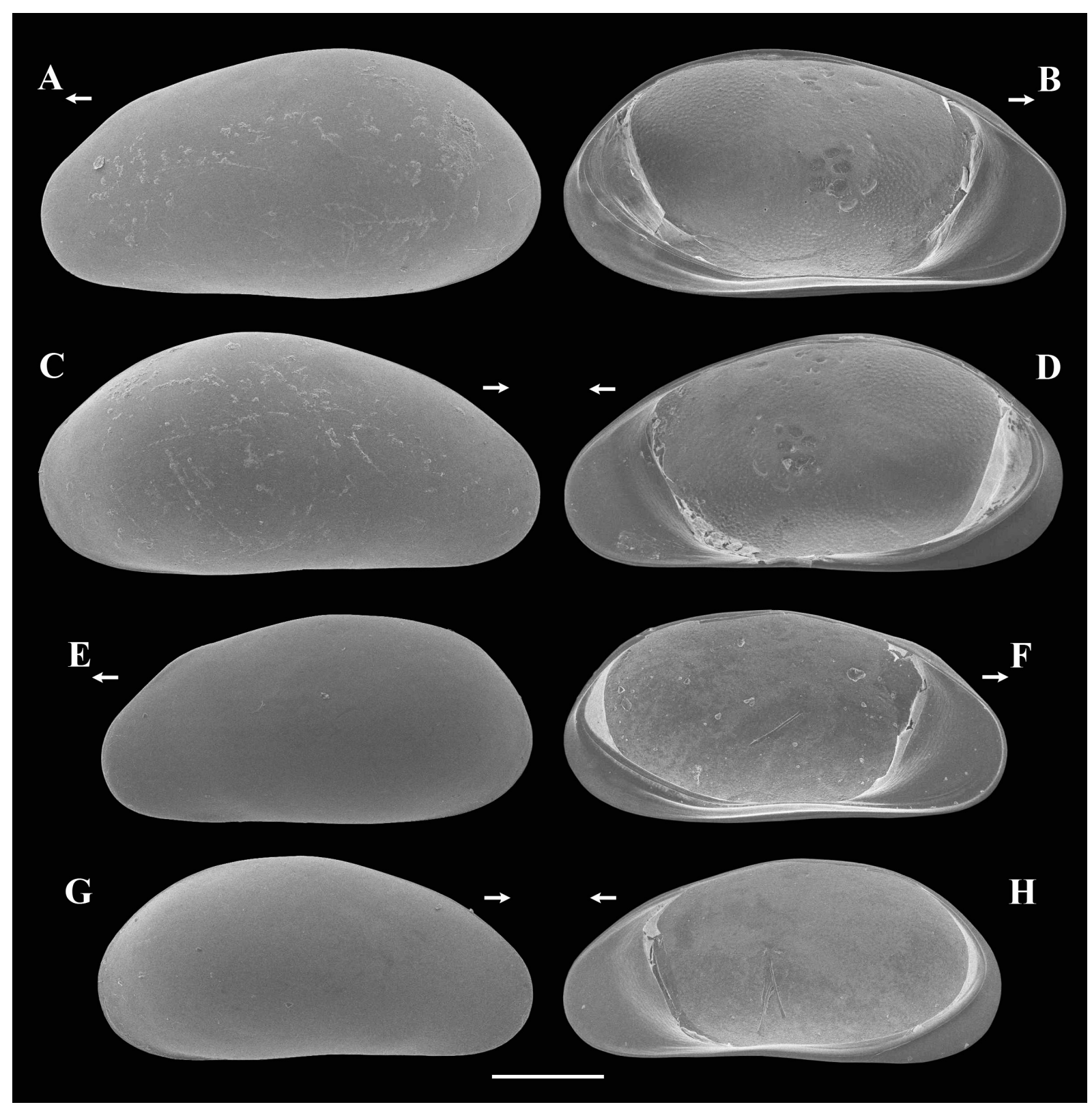

Fig. 1. Thaicypris panhai gen. et sp. nov. A-D. Holotype, $\uparrow$ (MSU-ZOC.314). E-H. Allotype, $\widehat{\jmath}$ (MSUZOC.315). A. LV, external view. B. LV, internal view. C. RV, external view. D. RV, internal view. E. LV, external view. F. LV, internal view. G. RV, external view. H. RV, internal view. Arrows point to anterior end of specimen. Scale bar $=500 \mu \mathrm{m}$. 

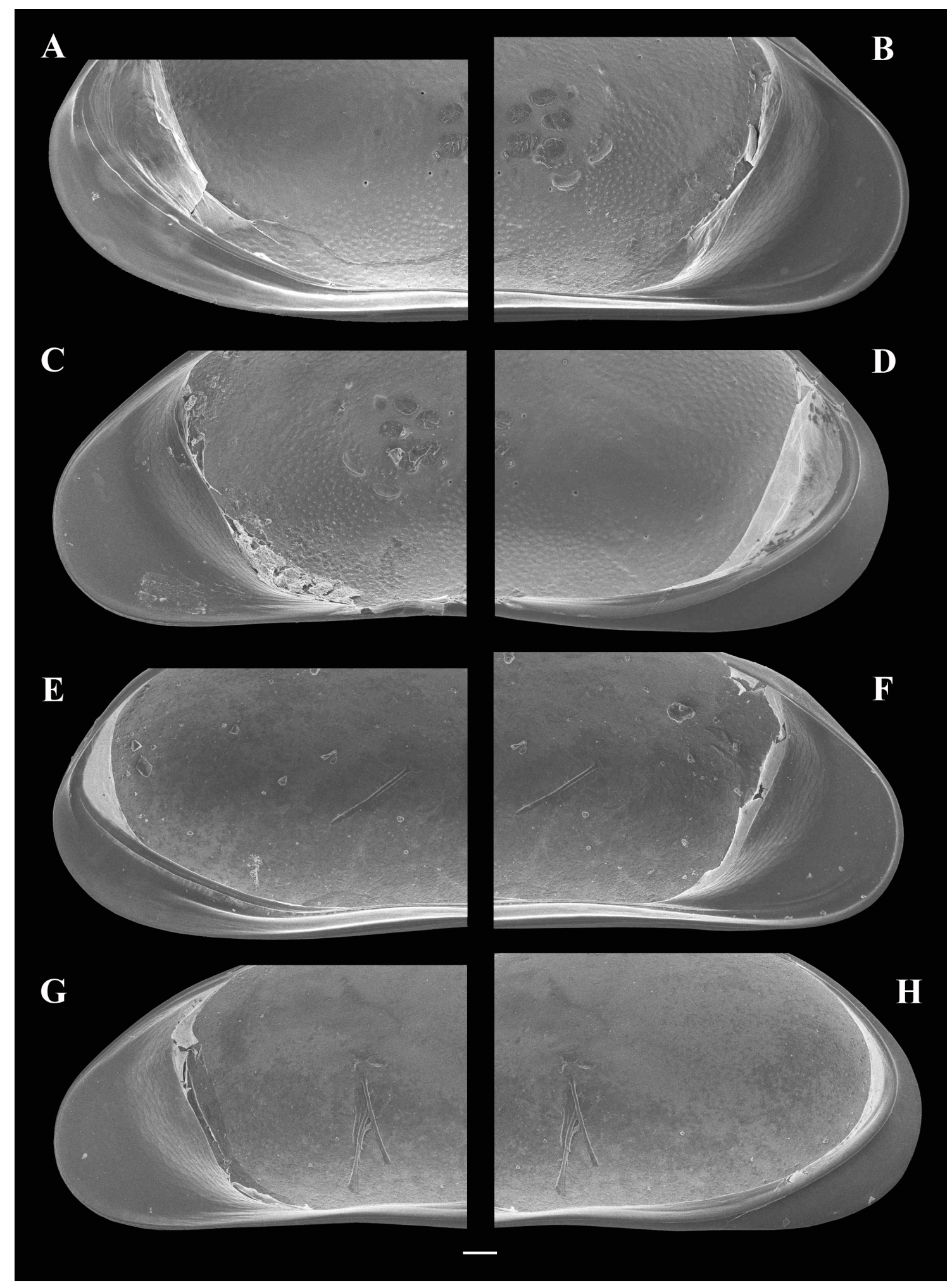

Fig. 2. Thaicypris panhai gen. et sp. nov. A-D. Holotype, $\uparrow$ (MSU-ZOC.314). E-H. Allotype, $\diamond$ (MSUZOC.315). A. LV, internal view, posterior part. B. LV, internal view, anterior part. C. RV, internal view, anterior part. D. RV, internal view, posterior part. E. LV, internal view, posterior part. F. LV, internal view, anterior part. G. RV, internal view, anterior part. H. RV, internal view, posterior part. Scale bar = $100 \mu \mathrm{m}$. 
A2 (Fig. 4D-E). Basal segment with two proximal setae and one long ventro-apical seta. Exopodite with three (one longer, two short) setae, longer one not reaching half of first endopodal segment. First endopodal segment with five long natatory setae (reaching slightly beyond tips of terminal claws) and one short accompanying seta (length ca $1 / 4$ that of penultimate segment), aesthetasc $Y$ very short and thin, situated at ca $1 / 4$ of its segment length, ventro-apical seta long, extending beyond tip of terminal segment. Penultimate segment undivided, distally with three large, serrated claws (G1-G3), aesthetasc y2 long (reaching slightly beyond tip of terminal segment), z1-z3 setae long, z1 shorter than other z setae, z2-z3 not reaching tip of claws G1-G3; this segment medially with two subequally short dorsal setae and four ventral setae of unequal length. Terminal segment with small ventro-apical projection set with fine marginal setules; distally with two serrated claws (GM and Gm), length of Gm ca $3 / 4$ that of GM, and with long g seta and aesthetasc $y 3$, length of aesthetasc y3 shorter than accompanying seta.

MD-PaLP (Fig. 5A-B). First segment with two large setae (S1 and S2), one long and slender seta, and $\alpha$-seta, the latter smooth, elongated with long, needle-like tip. Second segment dorsally with three unequally long apical setae, shortest seta almost reaching tip of next segment; ventrally with group of three long setae, one shorter hirsute seta and cone-shaped $\beta$-seta with pointed tip and set with a few long and strong setules. Penultimate segment bearing three groups of setae: dorsally with group of four unequal, long, subapical setae; laterally with apical $\gamma$-seta and three further apical setae, the former large, elongated (length ca 1.9 times that of terminal segment), distally covered with long setules ca $2 / 3$ of its length, the latter subequal in length (length of the longest seta ca 2 times terminal segment length, the shortest slightly beyond tip of terminal segment); ventrally with two subapical setae, one very long (length ca 3 times that of terminal segment), one shorter (reaching slightly beyond tip of terminal segment). Terminal segment bearing three claws and four setae, length of terminal claws ca 2.8 times that of terminal segment.

Mx1 (Fig. 5C). With two-segmented palp, basal segment of palp dorsally with group of six long, unequal apical setae; ventrally with one subapical seta (reaching tip of terminal segment), terminal segment spatulated, apically with three claws and three setae. Two large bristles on third endite smooth. Two sideways-directed bristles on first endite long, subequal in length.

T1 (Fig. 5D-E). Protopodite with two short a-setae, subequal in length, and long b-and d-setae, c-seta absent; distally with 10 hirsute apical setae of unequal length and four subapical setae, two of subapical setae short and stout. Endopodite very elongated; weakly built palp with three (one long, two short) apical setae, length of long one ca 2.7 times that of shortest one.

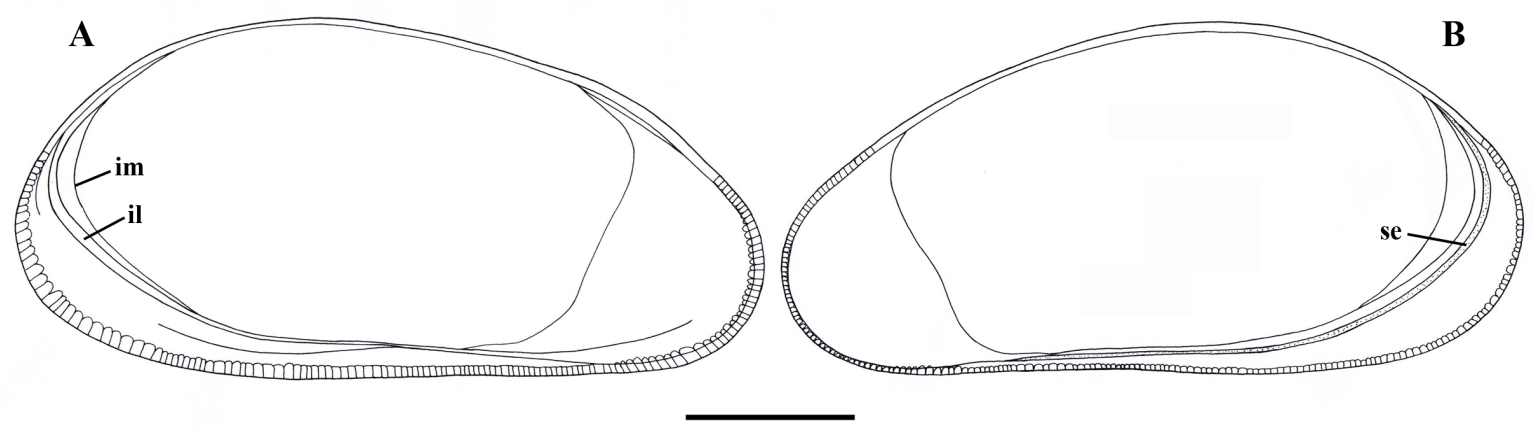

Fig. 3. Thaicypris panhai gen. et sp. nov., holotype, $q$ (MSU-ZOC.314). A. LV, internal view. B. RV, internal view. Scale bar $=500 \mu \mathrm{m}$. 


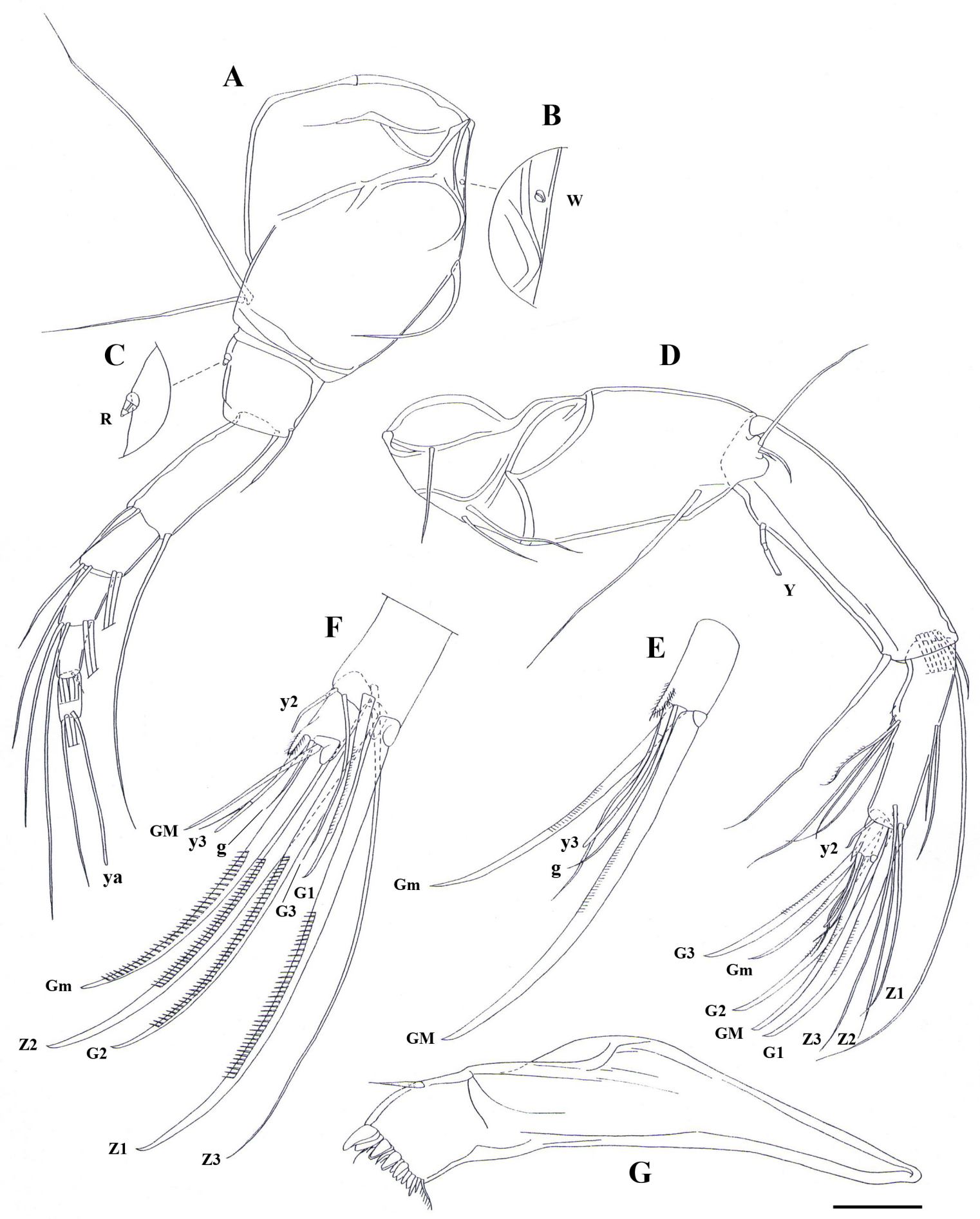

Fig. 4. Thaicypris panhai gen. et sp. nov. A-E, G. Holotype, $q$ (MSU-ZOC.314). F. Allotype, $\hat{\partial}$ (MSUZOC.315). A. A1. B. A1, Wouters organ. C. A1, Rome organ. D. A2. E. A2, terminal segment. F. A2, terminal part. G. Md-coxa. Scale bar: A, D, G $=100 \mu \mathrm{m}$; B-C, E-F $=50 \mu \mathrm{m}$. 


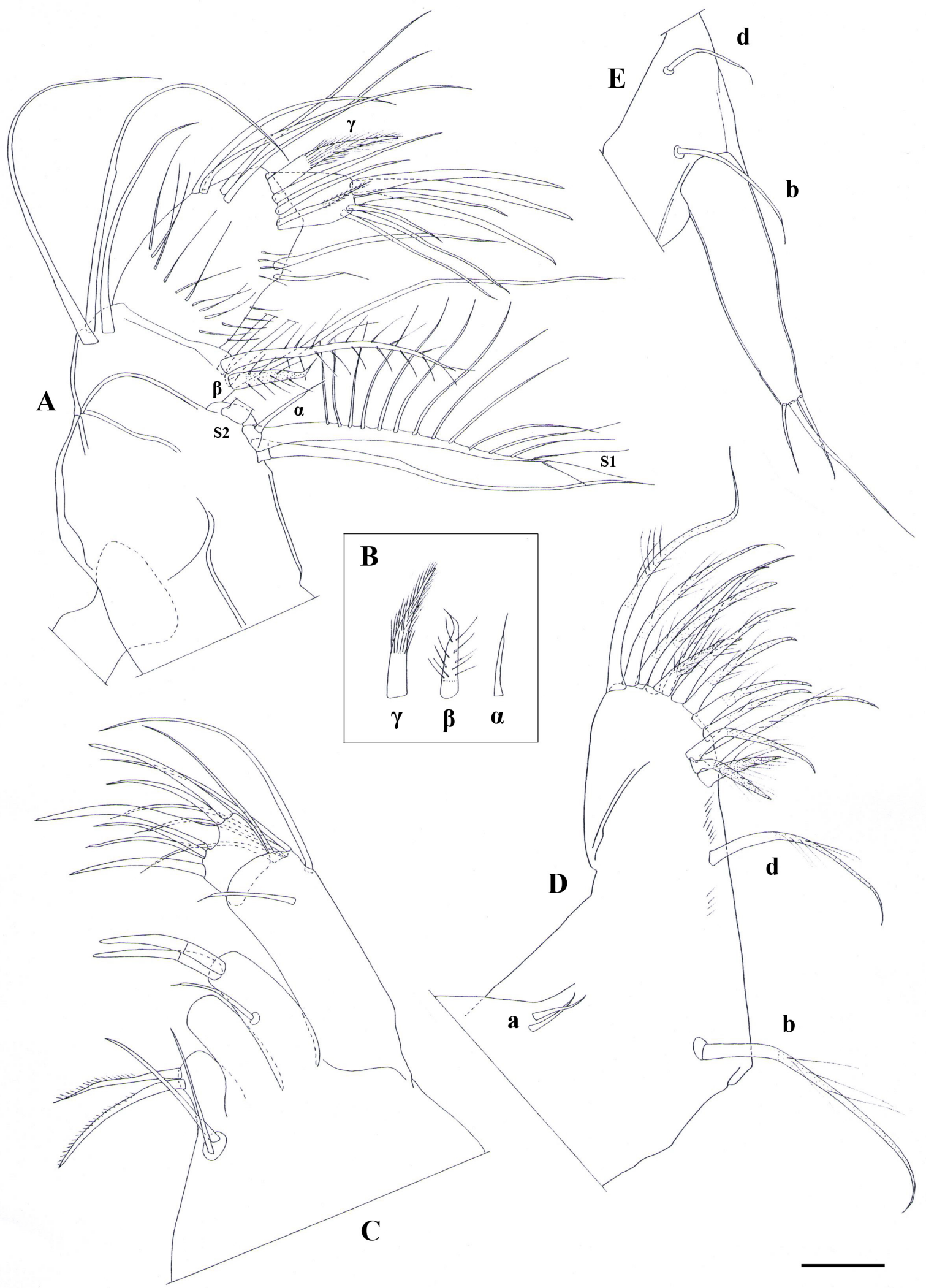

Fig. 5. Thaicypris panhai gen. et sp. nov., holotype, + (MSU-ZOC.314). A. Md-palp. B. Md-palp, $\alpha, \beta$, $\gamma$ setae. C. Mx1. D. T1. E. T1, palp (endopodite). Scale bar: A-D $=50 \mu \mathrm{m} ; \mathrm{E}=100 \mu \mathrm{m}$. 

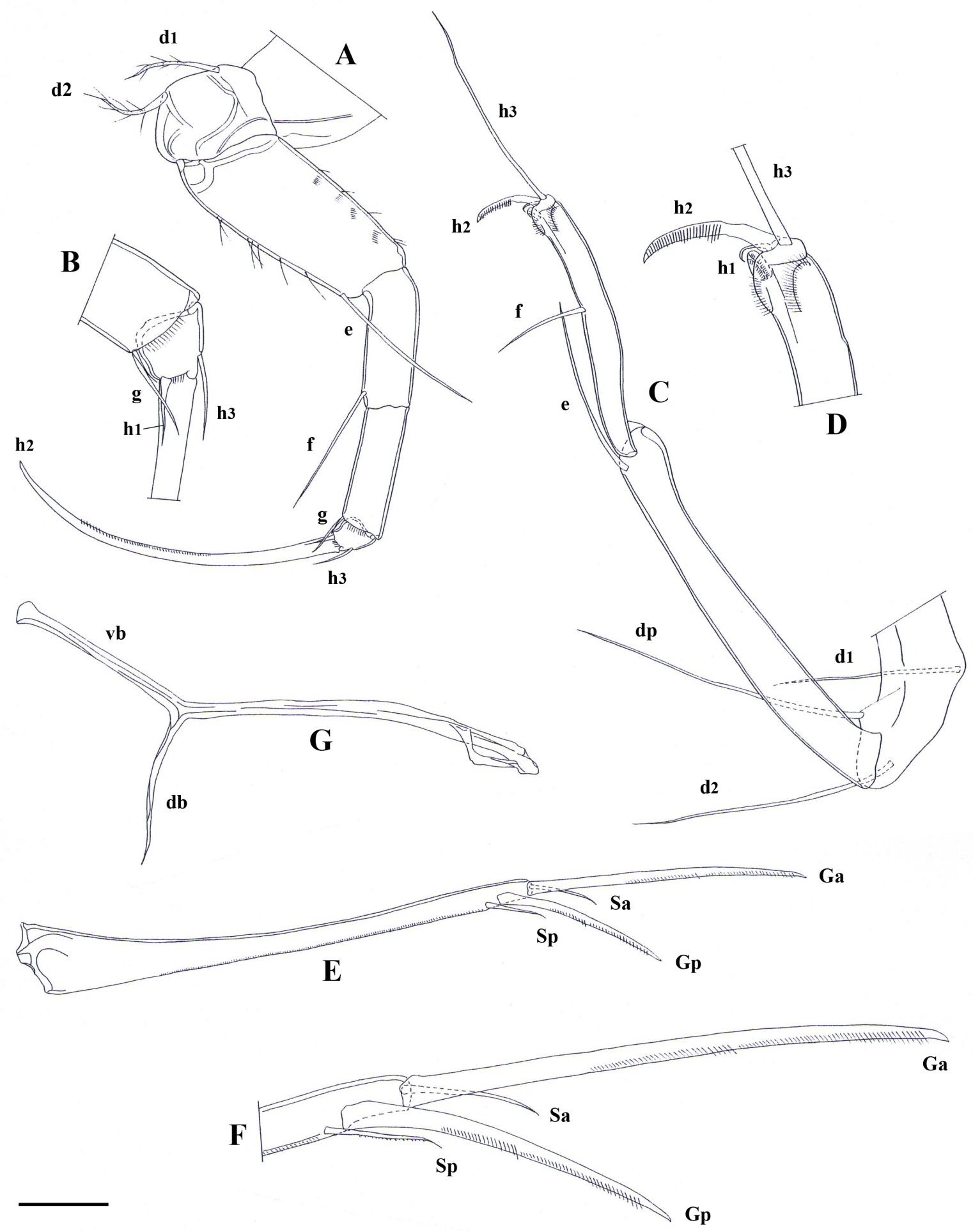

Fig. 6. Thaicypris panhai gen. et sp. nov., holotype,, (MSU-ZOC.314). A. T2. B. T2, terminal segment. C. T3. D. T3, terminal part. E. CR. F. CR, terminal part. G. CR attachment. Scale bar: A, C, E, G = $100 \mu \mathrm{m} ; \mathrm{B}, \mathrm{D}, \mathrm{F}=50 \mu \mathrm{m}$. 
T2 (Fig. 6A-B). With d1 and d2 setae subequal in length. Second segment with short e-seta (reaching beyond mid-length of penultimate segment). Penultimate segment divided, medially with long f-seta (reaching beyond tip of terminal segment), distally with apical g-seta and one short accompanying seta (length ca half that of g-seta). Terminal segment with two (one dorsal, one ventral) short apical h1 and h3 setae (subequal in length) and serrated claw (h2), length of $\mathrm{h} 2$ longer than that of penultimate segment.

T3 (Fig. 6C-D). First segment with long d1, d2 and dp setae, all subequal in length. Second segment with medium-length apical e-seta (reaching mid-length of next segment). Third segment with f-seta (not reaching tip of segment). Terminal segment with pincer organ and bearing short h1 seta, claw-like h2 seta and long h3 seta.

CR (Fig. 6E-F). Symmetrical with slender ramus and claws, ventral margin of ramus with tiny setules, claw Ga long (length ca half that of ramus), claw Gp short (less than half length of claw Ga), Sa seta short, Sp seta long and slender (true seta), reaching beyond tip of ramus. CR attachment (Fig. 6G) thin, with basal triangle and two-branched distal part.

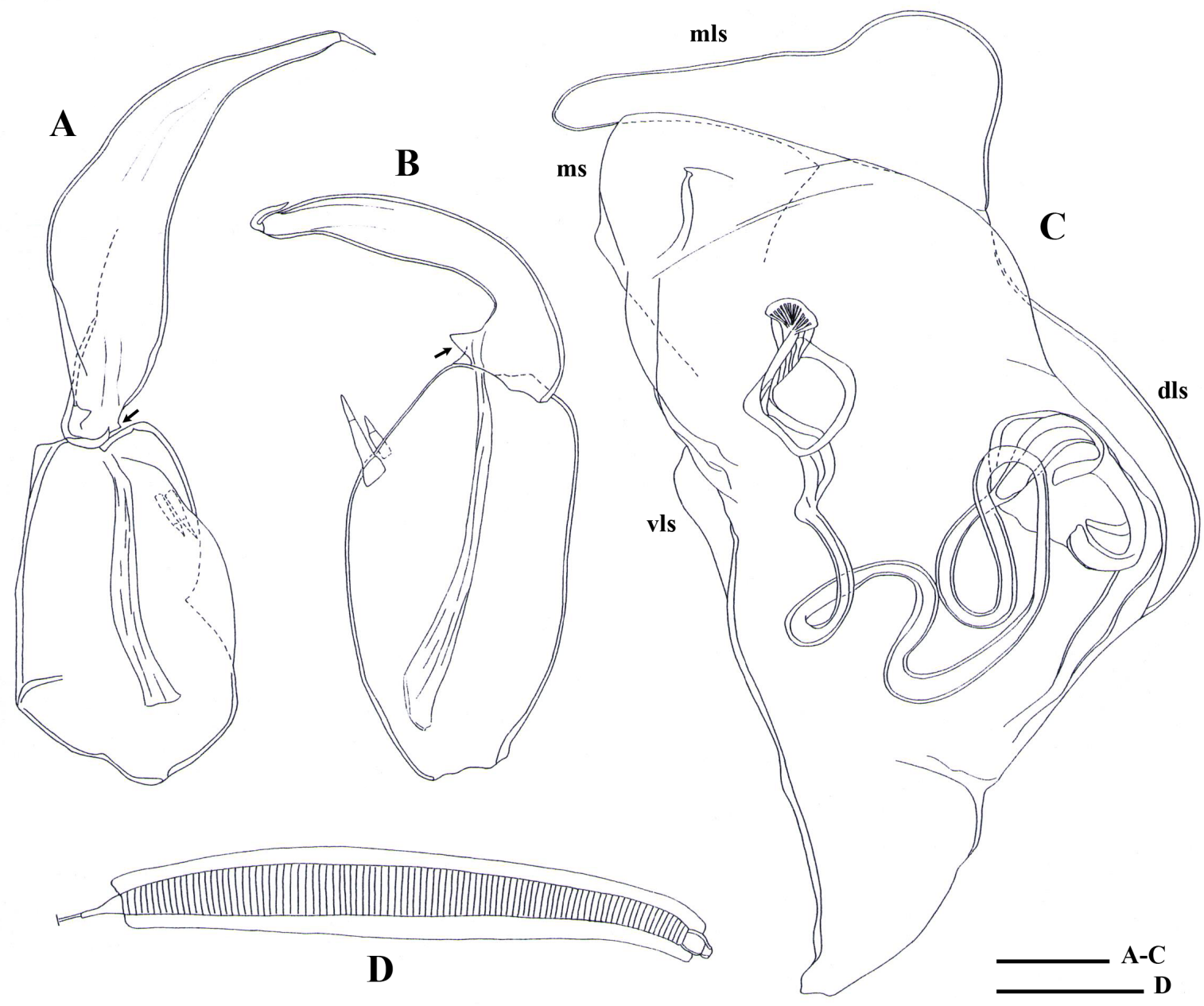

Fig. 7. Thaicypris panhai gen. et sp. nov., allotype, $\widehat{o}$ (MSU-ZOC.315). A. T1, right palp. B. T1, left palp. C. Hemipenis. D. Zenker organ. Arrows on A-B indicate the small pointed projection at the inner base of the terminal segment. Scale bars: $A-C=50 \mu \mathrm{m} ; \mathrm{D}=100 \mu \mathrm{m}$. 
Male

MeAsurements (in mm). LV: $\mathrm{L}=1952, \mathrm{H}=952$; $\mathrm{RV}: \mathrm{L}=1929, \mathrm{H}=905$.

Carapace and valves as in female, although somewhat smaller (length ca $2 \mathrm{~mm}$ ) (Fig. 1E-H). All limbs as in female, except for last two segments of A2, T1 and reproductive organs. Penultimate segment of A2 with claw-like z1 and z2 setae, considerably reduced claw G1 and with claw G3 reduced to thin setae; terminal segment with claw GM considerably reduced to thin setae, claw Gm large, with stronger teeth, length of GM ca half length of Gm (Fig. 4F). T1-endopodites forming asymmetrical prehensile palps; right palp (Fig. 7A) with two subapical spines on basal segment, terminal segment subtriangular; left palp (Fig. 7B) with two subapical spines on basal segment, terminal segment hook-like, inner base of terminal segment of both palps with small projection, one on left palp larger than on right palp.

Hemipenis (Fig. 7C). With ms subrectangular, widely rounded distal margin, without elongated protrusion, vls small and rounded (not finger-like), dls with round margin, without protrusion, distal part of mls proximally knob-like rounded and markedly long, beak-like apically. Postlabyrinthal spermiduct curved, with one loop. Zenker's organ (Fig. 7D) slender, elongated and set with numerous spiny whorls (more than 60 spiny whorls).

\section{Remarks}

The basal triangle of the CR-attachment (Fig. 6C) was narrow and located on the side of the dorsal branch. This aspect seems to be unusual, which possibly results from the distortion of the structure under the microscope. As only one male specimen has been encountered, the variability of the male appendages and reproductive organs is unknown.

\section{Discussion}

Given the presence of the basal triangle on the CR attachment, the Thai species undoubtedly belongs to the subfamily Herpetocypridinae. At first glance, the shape outline of the $\mathrm{Cp}$ in lateral view of the new species is similar to that of Stenocypria (see Scharf et al. 2020) and Humphcypris Martens, 1997 (see, e.g., Martens 1997). However, the detailed morphology of the valves and soft parts indicates that this Thai taxon cannot be placed in these genera. For example, the new species has inwardly displaced selvage on the RV and the inner lists on the LV, while in Stenocypria, the inwardly displaced selvage and inner list are absent on both valves. The shape of the terminal segment of the Mx1-palp is also different; it is spatulated in the new species but rectangular in Stenocypria and Humphcypris. The new species has a slender Sp seta on the CR, instead of a spine-like Sp seta or no Sp seta, which is a characteristic feature of Humphcypris. Apart from the similarity of the outline of the Cp shape, the soft parts of Humphcypris show many differences from the new species, especially the CR morphology, the natatory setae on the A2, the $\mathrm{d} 1$ and $\mathrm{d} 2$ setae on the $\mathrm{T} 2$ and the hemipenis features. The new species displays morphological characteristics which it shares with several genera of Herpetocypridinae, together with the unique characters (see discussion below). The combination of these features in the new species entails that it cannot be placed in any genus of the subfamily. To accommodate this species, the new genus, Thaicypris gen. nov., is thus erected.

The main characteristics of Thaicypris gen. nov. are the distinctive and raised, inwardly displaced selvage at the postero-ventral part of the RV which is not parallel to the valve margin, the absence of an anterior inner list of the RV, the prominent and elevated double posterior inner list on the LV, the small and three-segmented Rome organ on the A1, the spatulated terminal segment of the Mx1-palp, the slender $\mathrm{CR}$, the basal triangle on the $\mathrm{CR}$ attachment, the pointed projection at the terminal segment base of the T1 prehensile palps and the long, beak-like protrusion on the distal part of the mls of the hemipenis. According to the diagnosis of the tribes provided by Martens (2001), characters of Thaicypris gen. nov. are most congruent to those of the Herpetocypridini, composed of three other genera: Candonocypris, 
Herpetocypris and Ilyodromus. The presence of the two setae on the T3 penultimate segment is an unparalleled character in Candonocypris which has never been found in any genera of the tribe, or even of the subfamily. Thus, based on this evidence, the new genus can simply be discriminated from Candonocypris.

In the tribe Herpetocypridini, Thaicypris gen. nov. closely resembles Herpetocypris and Ilyodromus. The new genus can be distinguished from these two genera by the presence of the prominent and raised, inwardly displaced selvage on the postero-ventral part of the RV, the double posterior inner list on the $\mathrm{LV}$, the $\mathrm{Cp}$ in lateral view having a considerably arched dorsal margin (somewhat straight in Herpetocypris and Ilyodromus), the number of claws and setae on the terminal segment of the Md-palp and the numerous (more than 60) spiny whorls of the Zenker organ. In addition, the morphology of the hemipenis in Thaicypris gen. nov. is outstanding. It is remarkably different from that of Herpetocypris (see Gonzalez Mozo et al. 1996) and Ilyodromus (see De Deckker 1981; Shearn et al. 2017) or even of other herpetocypridine genera. The long, beak-like distal part of the mls of the new genus has never been recognized from any members of the subfamily. In Herpetocypris, the mls is a slightly convex lobe and considerably lower than the ms, whereas in Ilyodromus it is elongated with a blunt end and subequal in length of the ms. Thaicypris gen. nov. has a small rounded vls but this part is large and finger-like in Herpetocypris. The dls has a rounded margin in the new genus while a small projection and a large protrusion occur on this part of Herpetocypris and Ilyodromus, respectively. The ms of the new genus is subrectangular with a wide distal margin, whereas it is globe-like in Herpetocypris and subquadrate with an elongated protrusion distally in Ilyodromus. The prehensile palps of Thaicypris gen. nov. clearly display an asymmetry that is unlike conditions in Herpetocypris and Ilyodromus, which have a somewhat symmetrical form. Also, the pointed projection at the inner base of the prehensile palps has only been found in the new genus, missing in the two related genera. The basal segments of the prehensile palps usually bear apical or subapical spine(s)/tubercle(s), but such structures are rarely found on the terminal segment. This exceptional projection should be valid at the generic and/or specific levels. Its status would be confirmed by the discovery of a second species in this genus.

Moreover, Thaicypris gen. nov. also differs from Herpetocypris by the absence of the inwardly displaced selvage on the LV (present in Herpetocypris), the subequal length of the $\mathrm{d} 1$ and $\mathrm{d} 2$ setae on the T2 (d2 seta longer than the $\mathrm{d} 1$ seta in Herpetocypris), the robust cone-shaped $\beta$-seta on the Md-palp which is set with few long and strong setules (elongated shape and hirsute in Herpetocypris), the slender CR (more robust in Herpetocypris), the fine setules on the ventral margin of the ramus (short spines and grouped in Herpetocypris). Although Thaicypris gen. nov. and Herpetocypris have the posterior inner list(s) on the LV, the aspect is obviously different. In the new genus, it is a double inner list appearing prominent and elevated and situated far from the valve margin, while in Herpetocypris the two inner lists are (slightly) separated and run parallel along the valve margin. The male A2 has a large comblike structure on the claw Gm in the Herpetocypris species (see Gonzalez Mozo et al. 1996), but it is less developed, bearing smaller teeth in Thaicypris gen. nov. Generally, the aspects of the male Gm, and also other apical claws and setae on the last A2 two segments, in the new genus resemble those in Stenocypria (see Scharf et al. 2020).

Thaicypris gen. nov. can additionally be distinguished from Ilyodromus by the small and three-segmented Rome organ on the A1 (considerably larger and two-segmented in Ilyodromus), the $\alpha$-seta on the Mdpalp appearing slender with narrow base (wide base in Ilyodromus), the large $\gamma$-seta the length of which is almost two times that of the terminal segment (less than 1.5 times in Ilyodromus) and the morphology of the CR. The ramus and claws of the new genus are noticeably slender while those of Ilyodromus are robust. In Thaicypris gen. nov., the Sp seta is a true seta, slender and long, which is remarkably different from the claw-like Sp seta in Ilyodromus. In addition, the inner pegs on the LV exist in Ilyodromus, but are missing in Thaicypris gen. nov. The inwardly displaced selvage on the poster-ventral part of the 
$\mathrm{RV}$, which is a diagnostic feature of the new genus, can also be seen in some species of Ilyodromus, e.g., I. intermedius Smith et al., 2011 (see Smith et al. 2011), I. substriatus Sars, 1894, and I. viridulus (Brady, 1886) (see Shearn et al. 2014). Nevertheless, these selvages are significantly different between the new genus and Ilyodromus. The inwardly displaced selvage is prominent and raised, as well as set apart from the valve margin in the former genus, whereas it is close and parallel to the valve margin in the latter group.

The representatives of the subfamily Herpetocypridinae reported from Thailand are Chrissia and Stenocypris (Savatenalinton \& Suttajit 2016; Moonchaisook \& Savatenalinton 2020), which belong to the tribe Stenocypridini. Therefore, Thaicypris panhai gen. et sp. nov. described here is the first member of the tribe Herpetocypridini recorded from Thailand and the second species from Southeast Asia, after Ilyodromus lanoaensis (see Victor \& Fernando 1981).

The Wouters organ is a sensory organ on the A1. The occurrence (presence/absence) of this organ serves as a taxonomic character at the generic or specific levels. For example, in Dentocypria Savatenalinton, 2017 (Cyclocypridinae, see Savatenalinton 2017a) and Siamopsis Savatenalinton, 2017 (Cypridopsinae, see Savatenalinton 2017b), this organ has been encountered in all members of the genus while in some genera, e.g., Cypretta Vávra, 1895 (Cyprettinae, see Smith \& Matzke-Karasz 2008; Cohuo-Durán et al. 2013; Savatenalinton 2018), no such organ has been found. In such cases, the presence/absence of this organ is thus a character of the genus. However, the organ is a specific feature in some other genera, such as Pseudostrandesia Savatenalinton \& Martens, 2009 and Strandesia (Cypricercinae, see Savatenalinton \& Martens 2009, 2010; Savatenalinton 2015, 2021), as it not present in all species of the genus. Smith \& Matzke-Karasz (2008) extensively investigated the Wouters organ in cypridoidean ostracods, including eight species belonging to six genera of Herpetocypridinae (Candonocypris, Chrissia, Herpetocypris, Ilyodromus, Psychrodromus, and Stenocypris). None of them possessed this organ. In Herpetocypridinae, a Wouters organ has so far been reported only from the South American genus, Paranacypris Higuti, Meisch \& Martens, 2009 (Tribe Psychrodromini Martens, 2001, see Higuti et al. 2009) and the Southeast Asian taxon, Thaicypris gen. nov. (present study). As these two genera are currently monospecific, it is premature to judge whether the organ is a generic or specific structure. The description of additional members of the genus will prove its character status. Thaicypris gen. nov. is therefore the first representative of the tribe Herpetocypridini in which a Wouters organ is recognized.

The morphology of the Rome organ also provides diagnostic features, such as its size and segmentation. As the apical section of the organ is usually delicate and can be absent, the number of segments should not be counted on this section (see Shearn et al. 2014). In Thaicypris gen. nov., the Rome organ is small but segmented into four. This aspect can be simply observed at a magnification of at least 400 times. However, the tiny portion at the tip is delicate; the number of segments is thus defined as three in the new genus. The number of segments is simply judged if the organ is large, as seen in, e.g., Ilyodromus, but the opposite situation occurs in some other genera. For example, in Herpetocypris and Humphcypris, which have small Rome organs, so far no segmentation has been mentioned. Hence, detailed observations of this organ will possibly provide more discriminating characters among genera/species.

The terminal segment of the Md-palp in the new genus is exceptional, as it possesses three claws and four setae. In other genera of Herpetocypridinae, the number of claws and setae on this segment is five (three claws and two setae) or six (three claws and three setae). The former occurrence can be found in, for example, Herpetocypris (Gonzalez Mozo et al. 1996), Ilyodromus (Shearn et al. 2014) and Stenocypria (Scharf et al. 2020), while the latter one is the situation in, for example, Humphcypris (Martens 1997), Paranacypris (Higuti et al. 2009) and Amphibolocypris Rome, 1965 (Jocque et al. 2010). This suggests that to obtain more taxonomic characters, more attention should be paid to detailed structures, such as the pattern of chaetotaxy on this segment, in further investigations. 


\section{Acknowledgements}

This research project was financially supported by Mahasarakham University. Two anonymous reviewers are gratefully thanked for their useful comments. Apirada Manpae (MSU, Thailand) offered technical assistance with the scanning electron micrographs.

\section{References}

Broodbakker N.W. \& Danielopol D.L. 1982. The chaetotaxy of Cypridacea (Crustacea, Ostracoda) limbs: proposals for a descriptive model. Bijdragen tot de Dierkunde 52 (2): 103-120. https://doi.org/10.1163/26660644-05202003

Cohuo-Durán S., Elías-Gutiérrez M. \& Karanovic I. 2013. On three new species of Cypretta Vávra, 1895 (Crustacea: Ostracoda) from the Yucatan Peninsula, Mexico. Zootaxa 3636 (4): 501-524. https://doi.org/10.11646/zootaxa.3636.4.1

De Deckker P. 1981. Ostracoda from Australian inland waters - notes on taxonomy and ecology. Proceedings of the Royal Society of Victoria 93 (1): 4-85.

Gonzalez Mozo M.E., Martens K. \& Baltanas A. 1996. Taxonomic revision of European Herpetocypris Brady and Norman, 1889 (Crustacea, Ostracoda). Bulletin van het Koninklijk Belgisch Instituut voor Natuurwetenschappen, Biologie 66: 93-132.

Higuti J., Meisch C. \& Martens K. 2009. On Paranacypris samambaiensis gen. nov., sp. nov. (Crustacea, Ostracoda), the first South American psychrodromid from the alluvial valley of the Upper Paraná River, Brazil. Journal of Natural History 43 (13-14): 769-783. https://doi.org/10.1080/00222930802702506

Jocque M., Brendonck L., Riddoch B.J. \& Martens K. 2010. On Amphibolocypris arida sp. nov. (Crustacea, Ostracoda), from rock pools in Botswana (southern Africa). Zootaxa 2408 (1): 47-58. https://doi.org/10.11646/zootaxa.2408.1.3

Martens K. 1987. Homology and functional morphology of the sexual dimorphism in the antenna of Sclerocypris Sars, 1924 (Crustacea, Ostracoda, Megalocypridinae). Bijdragen tot de Dierkunde 57 (2): 183-190. https://doi.org/10.1163/26660644-05702003

Martens K. 1997. Two new crenobiont ostracod genera (Crustacea, Ostracoda, Herpetocypridinae) from Africa and Asia Minor, with the description of a new species from dolomitic springs in South Africa. South African Journal of Science 93: 542-554.

Martens K. 2001. Taxonomy of the Herpetocypridinae (Ostracoda, Cyprididae). Crustaceana 74 (3): 295-308. https://doi.org/10.1163/156854001505532

Meisch C. 2000. Freshwater Ostracoda of Western and Central Europe. In: Schwoerbel J. \& Zwick P. (eds) Süßwasserfauna von Mitteleuropa vol. 8 (3). Spektrum Akademischer Verlag, Heidelberg, Berlin.

Meisch C., Smith R.J. \& Martens K. 2019. A subjective global checklist of the extant non-marine Ostracoda (Crustacea). European Journal of Taxonomy 492: 1-135. https://doi.org/10.5852/ejt.2019.492

Moonchaisook K. \& Savatenalinton S. 2020. Redescriptions of Stenocypris major major (Baird, 1859) and Stenocypris major sketi Petkovski \& Meisch, 1996 (Ostracoda: Crustacea), with discussion on their taxonomic position. Zootaxa 4786 (4): 497-515. https://doi.org/10.11646/zootaxa.4786.4.3

Savatenalinton S. 2015. On three new species of non-marine ostracods (Crustacea: Ostracoda) from Northeast Thailand. Zootaxa 3914 (3): 275-300. https://doi.org/10.11646/zootaxa.3914.3.3

Savatenalinton S. 2017a. A new genus and four new species of subfamily Cyclocypridinae (Crustacea, Ostracoda) from Thailand. Zootaxa 4243 (2): 329-365. https://doi.org/10.11646/zootaxa.4243.2.4 
Savatenalinton S. 2017b. Siamopsis gen. nov. and five new species of the subfamily Cypridopsinae Kaufmann, 1900 (Crustacea: Ostracoda) from Thailand. European Journal of Taxonomy 384: 1-39. https://doi.org/10.5852/ejt.2017.384

Savatenalinton S. 2018. Two new species of Cypretta Vávra, 1895 (Crustacea, Ostracoda) from Thailand and a discussion of genus. Zootaxa 4532 (4): 483-502. https://doi.org/10.11646/zootaxa.4532.4.2

Savatenalinton S. 2021. Two new species of Cypricercinae McKenzie, 1971 (Crustacea, Ostracoda) from Thailand. European Journal of Taxonomy 733: 19-41. https://doi.org/10.5852/ejt.2021.733.1217

Savatenalinton S. \& Martens K. 2009. Generic revision of Cypricercinae McKenzie, 1971 (Crustacea, Ostracoda), with the description of three new genera and one new species and a phylogenetic analysis of the subfamily. Hydrobiologia 632 (1): 1-48. https://doi.org/10.1007/s10750-009-9826-5

Savatenalinton S. \& Martens K. 2010. On the subfamily Cypricercinae McKenzie, 1971 (Crustacea, Ostracoda) from Thailand, with the description of six new species. Zootaxa 2379 (1): 1-77.

https://doi.org/10.11646/zootaxa.2379.1.1

Savatenalinton S. \& Suttajit M. 2016. A checklist of recent non-marine ostracods (Crustacea: Ostracoda) from Thailand, including descriptions of two new species. Zootaxa 4067 (1): 1-34.

https://doi.org/10.11646/zootaxa.4067.1.1

Scharf B., Meisch C., Kulkoyluoglu O. \& Yavuzatmaca M. 2020. Stenocypria fischeri (Lilljeborg, 1883), a poorly known freshwater ostracod (Crustacea, Ostracoda). Bulletin de la Société des Naturalistes luxembourgeois 122: 217-238.

Shearn R., Halse S., Koenders A., Schön I. \& Martens K. 2014. Redescription of six species of Ilyodromus Sars, 1894 (Crustacea, Ostracoda, Cyprididae) from New Zealand and Eastern Australia. Zootaxa 3878 (2): 101-145. https://doi.org/10.11646/zootaxa.3878.2.1

Shearn R., Schön I., Martens K., Halse S., Krawiec J. \& Koenders A. 2017. Patterns of genetic divergence in the Ilyodromus amplicolis lineage (Crustacea, Ostracoda), with descriptions of three new species. Zootaxa 4318 (1): 1-46. https://doi.org/10.11646/zootaxa.4318.1.1

Smith R.J. \& Matzke-Karasz R. 2008. The organ on the first segment of the cypridoidean (Ostracoda, Crustacea) antennule: morphology and phylogenetic significance. Senckenbergiana Lethaea 88 (1): 127-140. https://doi.org/10.1007/BF03043984

Smith R.J., Janz H. \& Okubo I. 2011. Recent Cyprididae and Ilyocyprididae (Crustacea: Ostracoda) from Lake Biwa, Japan, including a summary of the lake's ostracod fauna. Zootaxa 2874 (1): 1-37. https://doi.org/10.11646/zootaxa.2874.1.1

Victor R. \& Fernando C.H. 1981. A new species of Ilyodromus Sars (Crustacea, Ostracoda) from the Philippines. Zoologica Scripta 10 (4): 255-257. https://doi.org/10.1111/j.1463-6409.1981.tb00501.x

Manuscript received: 24 September 2021

Manuscript accepted: 27 October 2021

Published on: 5 January 2022

Topic editor: Tony Robillard

Desk editor: Pepe Fernández

Printed versions of all papers are also deposited in the libraries of the institutes that are members of the EJT consortium: Muséum national d'histoire naturelle, Paris, France; Meise Botanic Garden, Belgium; Royal Museum for Central Africa, Tervuren, Belgium; Royal Belgian Institute of Natural Sciences, 
Brussels, Belgium; Natural History Museum of Denmark, Copenhagen, Denmark; Naturalis Biodiversity Center, Leiden, the Netherlands; Museo Nacional de Ciencias Naturales-CSIC, Madrid, Spain; Real Jardín Botánico de Madrid CSIC, Spain; Zoological Research Museum Alexander Koenig, Bonn, Germany; National Museum, Prague, Czech Republic. 